\title{
Suicide attempts at the age of 10-18 in Lublin
}

\author{
Probibsamobobice podémownane w wieku 10-18 lat w Lublinie
}

\section{Małgorzata Pabiś ๑, Kinga Augustowska-Kruszyńska ๑}

\begin{abstract}
Katedra Rozwoju Pielęgniarstwa, Zakład Podstaw Pielęgniarstwa i Dydaktyki Medycznej, Wydział Nauk o Zdrowiu, Uniwersytet Medyczny w Lublinie/ Chair of Development in Nursing, Department of Basic Nursing and Medical Teaching, Faculty of Health Sciences, Medical University of Lublin, Poland
\end{abstract}

CORRESPONDING AUTHOR/AUTOR DO KORESPONDENCJI:

Małgorzata Pabiś

Katedra Rozwoju Pielęgniarstwa, Zakład Podstaw Pielęgniarstwa i Dydaktyki Medycznej, Uniwersytet Medyczny w Lublinie ul. Staszica 4/6, 20-081 Lublin e-mail: malgorzata.pabis@umlub.pl

STRESZCZENIE

Słowa kluczowe:

ABSTRACT

Key words:

\section{PRÓBY SAMOBÓJCZE PODEJMOWANE W WIEKU 10-18 LAT W LUBLINIE}

Wprowadzenie. Z roku na rok wzrasta liczba dzieci i młodzieży hospitalizowanych z powodu podejmowanych prób samobójczych, których powodem jest stres, niska samoocena, brak akceptacji i przemoc rówieśnicza, oraz problemy rodzinne. Dodatkowo może występować zaburzony obraz postrzegania siebie czy depresję. Jest to zjawisko bardzo złożone, którego skala powinna skłaniać do podjęcia natychmiastowych wielowymiarowych działań.

Cel pracy. Analiza występowania prób samobójczych wśród nieletnich na przykładzie miasta Lublina.

Materiał i metoda. Dokonano analizy danych statystycznych uzyskanych z Komendy Głównej Policji i na podstawie Raportu Fundacji Dajemy Dzieciom Siłę „Dzieci się liczą 2017" oraz przegląd literatury przedmiotu za lata 2014-2018 opracowane za pomocą metody opisowej.

Wyniki. Raport Fundacji Dajemy Dzieciom Siłę pokazuje ogromną skalę zjawiska. Zgodnie zjego danymi aż 72\% dzieci w wieku 11-17 lat doświadczyło w swoim życiu co najmniej jednej formy krzywdzenia, 7\% badanych podjęło próbę samobójczą, a 16\% nastolatków okaleczało się. Statystyki prowadzone w Polsce w latach 2017-2018 zanotowały w 2017 roku 116, a w 2018 roku 97 zamachów samobójczych zakończonych zgonem. Na województwo lubelskie przypadło 5 zgonów w 2017 roku i 9 w 2018 roku, co ukazuje $80 \%$ wzrost w ciągu 12 miesięcy. W grupie wiekowej 7-12 lat w 2017 roku zanotowano tylko jeden zamach samobójczy zakończony zgonem, w 2018 roku liczba wzrosła do 5 - żaden z nich nie dotyczył województwa lubelskiego.

Wnioski. Próby samobójcze zakończone zgonem w 2018 roku stanowiły 2,30\% prób samobójczych podjętych w Lublinie, zaś w Polsce stanowiły 1,87\%. Głównymi powodami prób samobójczych podejmowanych przez nieletnich są: brak akceptacji, niska samoocena oraz przemoc rówieśnicza zarówno fizyczna jak i psychiczna. Mass media mają wpływ na podejmowane samobójstwa przez nieletnich. Wiara w „kilka żyć" utrwalana poprzez gry komputerowe i filmy, może mieć wpływ na podejmowanie prób samobójczych. próba samobójcza, nieletni, Lublin

\section{SUICIDE ATTEMPIS AT THE AGE 0F 10-18 IN LUBLIN}

Introduction. The number of children and adolescents hospitalized due to suicide attempts caused by stress, low self-esteem, lack of acceptance and peer violence, as well as family problems, increases every year. In addition, there may occur disturbed self-perception or depression. This is a very complex phenomenon, the scale of which should induce immediate multidimensional activities.

Aim. Analysis of the occurrence of suicide attempts among minors on the example of the city of Lublin.

Material and methods. The statistical data obtained from the Polish Police Headquarter and from the report of the Foundation We Give Children Strength - "Children count 2017" was analyzed and a review of the literature on the subject for the years 2014-2018 developed using the descriptive method was made.

Results. The report of the Foundation We Give Children Strength shows a huge scale of the phenomenon. According to its data, as many as $72 \%$ of children aged $11-17$ have experienced at least one form of abuse in their lives, $7 \%$ of respondents have attempted suicide, and 16\% of teenagers have mutilated themselves. The statistics conducted in Poland in 2017-2018 recorded: in 2017 the number of 116, and in 2018 - 97 suicide attempts ended in death. There were 5 deaths in 2017 and 9 in 2018 in Lubelskie Voivodeship, what shows an increase by $80 \%$ in 12 months. In the 7-12 age group in 2017 , only one suicide attempt ended up in death was reported, in 2018 the number increased to 5 - none of them concerned the Lublin Province.

Conclusions. Suicide attempts ending up in death in 2018 accounted for $2.30 \%$ of suicide attempts undertaken in Lublin, while in Poland they constituted $1.87 \%$. The main reasons for suicide attempts among minors are: the lack of acceptance, low self-esteem and peer violence, both physical and mental. Mass media have an influence on juvenile suicides. Belief in "multiple lives" perpetuated by computer games and films can have an impact on suicide attempts. 


\section{INTRODUCTION}

In recent years an increase in the number of children and adolescents provided with specialist psychiatric or psychological care due to mental disorders has been observed. The analyzed data [1] showed that in 2015 over 143 thousand of children and adolescents up to 18 years of age, out of whom $61 \%$ constituted boys, benefited from the specialist care. In this period 481 suicide attempts were noted, among which as many as 12 were made by children under 12 years old. The analysis also shows that, taking into account quantity, suicides were the second cause of deaths in the age group 10-19 years. The suicide attempts ended up in death were more frequently made by boys. In 2014 Poland was in the second position in Europe (after Germany) when it comes to number of suicide attempts ended up in death among children and adolescents up to 19 years of age [1]. Experiencing abuse in childhood is not only the cause of physical injuries or psychosocial developmental disorders, but it may also lead to the risk of becoming abuser, to mental disorders, anxieties, self-mutilation, suicide attempts or other self-destructive behaviors $[2,3,4,5]$.

What is terrifying while analyzing the issue of suicide, is the fact that suicide attempts are made by children under 12. In 2014 in Poland in this group 14 attempts were noted, in two following years the number decreased, and in 2017 the number was doubled. In the analyzed years (2014-2018) the biggest number of suicide attempts was made in Katowice, Kraków and Łódź. It was also reflected in the quantity of such attempts in the age group 13-18 years. During the five-year-long observation the increase by $42.63 \%$ in this group was noticed. An upward trend concerning number of suicide attempts during the five-year-long observation was noticed in Lublin (13.07\%) and in Poland (8.60\%). Suicide attempts ended up in death were also analyzed. Both in Lublin and in Poland a downward trend was observed when it comes to number of people who made a suicide attempt ended in death in general population. In the analyzed period the suicide attempts and those ended up in death in Poland were made on Monday [6].

\section{AIM}

The aim of the work was an analysis of the occurrence of suicide attempts among minors on the example of the city of Lublin.

\section{MATERIAL AND METHODS}

The statistical data obtained from the Polish Police Headquarters and from the report of the Foundation We Give Children Strength - „Children count 2017” was analyzed and a review of the literature on the subject for the years 2014-2018 developed using the descriptive method was made. The data concerned suicides ended in death and included the specific information: age group, day of the week, place and cause, education. Two age groups, 7-12 and 13-18 years old, were included into the analyses.
The group 0-6 years old was excluded from the analyses because no suicide attempts were found in this group.

\section{RESULTS}

In the age group 7-12 years old in Lublin, in the five-year-long observation, the trend was constant. In 2014 there were three suicide attempts, in 2015 - one was noted, in 2016 - there were not any attempts, in 2017 - there were four of them, and in 2018 - three suicide attempts. In Poland in the same period and the same age group, the trend was sharply upward and was equal to $46.15 \%$. In 2014 - fourteen attempts were noted, in two following years the number decreased (in 2015 12, in 2016 - 9 attempts), in 2017 the number of suicide attempts in the discussed age group increased by $100 \%$ and was equal to 28 , and in 2018 it slightly decreased (26 suicide attempts) [6].

Similar trend, both in Lublin and in Poland, was observed in the age group 13-18 years. In five-year-long observation an increase by $26.19 \%$ concerning suicide attempts in Lublin was observed. In $2014-31$ attempts were noted, in $2015-25$, in $2016-20$, in $2017-26$, and in $2018-42$ suicide attempts (Figure 1). In Poland in the same period and the same age group, the trend concerning suicide attempts was also upward and an increase by $42.63 \%$ was observed. In 2014 - 428 suicide attempts were noted, in 2015 - 469, in 2016 there was a slight decrease to 466 cases, in 2017 - an increase to 702 ones and in 2018 there were 746 suicide attempts [6].

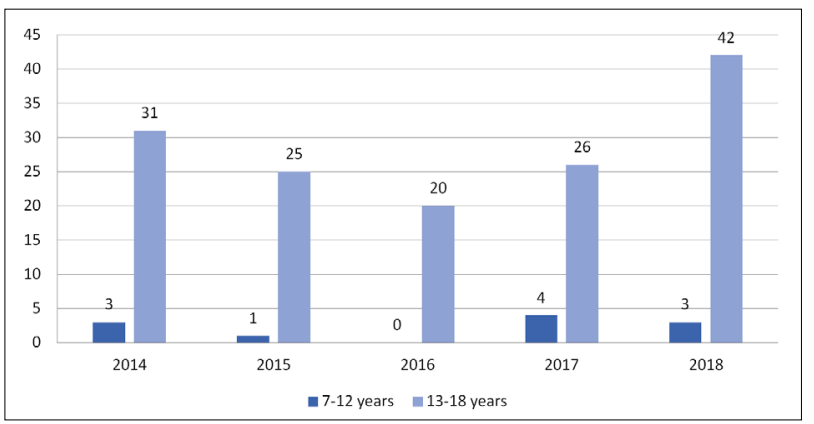

Fig 1. Suicide attempts among children and adolescents in Lublin in the years 2014-2018

Source: Own analysis on the basis of statistical data of the Polish Police Headquarter from the years 2014-2018.

The place of suicide attempts among children and youth in Lublin were educational care facilities and school. Figures from the years 2014-2016 are unavailable. In the educational care facilities in Lublin an increase in the number of suicide attempts by $60 \%$ was noted in the analyzed period of time. In 2017 - 2 attempts were made, and in 2018 - 5 suicide attempts. In schools two and a half times decrease was noted. In 2017 there were 5, and in 2018 - two suicide attempts. In Poland a decrease by 9.09\% was observed when it comes to suicide attempts in educational care facilities in the analyzed period of time. In 2017 - 48 attempts were noted, and in 2018 - 44 ones. In schools, similarly to Lublin, a decrease was noted by $18.75 \%$. In 2017 - 57 cases were found, and in $2018-48$ attempts in school [6]. 
In the age group 7-12 years in the five-year-long observation in Lublin the trend concerning suicide attempts ended up in death is downward. In 2014 there was one case of such death, while in the following years (20152018) there were not any cases of death resulting from suicide attempt. In Poland in the same period and the same age group, the trend was changeable and eventually an increase by two deaths was noted. In 2014 there were 3 fatal cases, in 2015 it increased to 5, in 2016 - decreased to 2 , in 2017 - decreased to 1 death, and in 2018 - there were 5 deaths noted [6].

Similar trend, both in Lublin and in Poland, was observed in the age group 13-18 years. In Lublin in 2014 and 2015 - 10 cases were noted, in 2016 - 11, in 2017 - decrease to 5, and in 2018 - increase to 9 fatal cases caused by suicide attempts. However, in the five-year-long observation, a decrease in the suicide attempts ended in death was found. The situation in Poland was similar, which means that downward tendency in the discussed age group and period was noted by $34.78 \%$. In 2014 - 124 suicides were confirmed, in 2015 - 114, in 2016 - decrease to 101, in 2017 - increase to 115 and in 2018 - 92 deaths after suicide attempts [6].

Suicides ended in death among children and adolescents took place in educational care facilities and in schools. Figures from the years 2014-2016 are unavailable. In Lublin in the educational care facilities no fatal cases caused by suicide were found. In 2017 and 2018 one death was noted in school. In Poland in the educational care facilities the number of fatal cases decreased from 3 in 2017 to 2 in 2018. In Poland there were 7 suicide attempts ended in death in school [6].

The studies $[7,8,9,10,11]$ show that the most frequent causes of attempted suicide among children and adolescents were the feeling of emotional rejection by parents, conflicts with parents, death of one or both parents, alcoholism of parents, conflicts between the parents, family structure, conflicts with siblings, lack of religiosity in the family, stolen money from the family, problems in relations with peers, having girlfriend/boyfriend or their lack, love failures, low position in the group, prohibitions binding in the group, compliance with the regulations, inability to realize own way of life, anxiety concerning new social roles, difficulty in making mature decisions, anxiety concerning own psychosexual identity, problems with biological maturation, lack of acceptance concerning own appearance.

\section{DISCUSSION}

As it was proved, the percentage of suicide among children and adolescents unfortunately increases. It is a worrying phenomenon which requires prevention. At the same time everybody should be aware of the fact that under some unfavorable conditions, coincidence, events and negative experiences, every human may experience suicidal thoughts [12].

Psychiatrists define the condition of a person who plans a suicide as a "tunnel vision", which is a state in which it seems that there is no hope and that the only escape from suffering may be destruction of own consciousness, own existence. It is not, however, a constant and unchangeable disposition, as in case of reducing the suffering as a result of satisfying the need, the suicide attempt is not made. That is why a part of the potential suicides earlier send some warning signals [13], which are, as it were, a chance for the environment to satisfy their need and relieve them from the suicidal thoughts [14].

The causes of suicides among children may be various, however it is always the feeling of lack of security resulting from, among others, separation from a friend or beloved person, relocation, arguments between the parents, domestic violence which a child cannot prevent, sticking out in the class, being not accepted by both the classmates and the teacher. What is the worst, however, is that even when the child or teenager communicates the problems to his/ her parents, those problems are trivialized and the child remains all alone with the problem which is, in his view, insoluble [15].

The studies of the New York psychiatrists conducted among 321 persons suffering from depression or bipolar affective disorder showed that more religious people (regardless of the religion) more often committed suicides - odds ratio 2.25 [16]. Although, it became the psychiatrists' practice to stimulate spirituality in patients in order to prevent suicide attempts, as spirituality as well as, offered by it, consolation, recognition and acceptance of events, and circumstances encountered by patient, provide an escape from the suicide attempts [14, 17]. However, it needs to be emphasized that, according to published in 2018 studies conducted by the New York State Psychiatric Institute and Columbia University - religiosity of parents decreases the chance of committing suicide by their children. The studies lasted for the period of 30 years and comprised 3 generations, 112 parents. The statistically significant relationships were found out between the belief that religion is important and lower probability of suicide attempts in the group of girls, between the religious practices and lower probability of attempted suicides in the group of girls, while the higher religiosity of parents was connected with smaller risk of suicidal thoughts and attempts among both, boys and girls. Perhaps it is associated with an observation of everyday life of the parents, who are role models for the child. They find the essence in faith and belong to the community, what results in creation of a kind of umbrella, protecting the child from the suicidal thoughts and attempts, and particularly the construction, which includes the sense of belonging, acceptance and life purpose [18].

It turns out, however, that not every religion protects from suicides. Suicide is a violation of the commandment "Do not kill" in Judaism and Christianity, condemned in Cardecism, Buddhism, Hinduism and Islam [14]. Even though in the Quran it is written: "But whoever kills a believer intentionally - his recompense is Hell, wherein he will abide eternally, and Allah has become angry with him and has cursed him and has prepared for him a great punishment" (Quran 4:93) [19], at the same time Sheikh Uthaymeen's translation says: "The Prophet said: "Indeed, whoever (intentionally) kills himself, then certainly he will be punished in the Fire of Hell, wherein he shall dwell forever" [al.-Bukhari, 5778 and Muslim: 109, 
110]. In reality, the one who commits suicide, generally does so because of his desperate situation, either as a direct result of an act of Allah or a human being. So you find him unable to cope with that which has afflicted him, and in actual fact he is like one who is calling for help from the scorching heat of the fire. So he has progressed from that which was tough (bad) to that which is worse. And if he was patient, then Allah would have assisted him in dealing with the difficulty" [20]. By contrast, the observed reality brings the suicides a justification with mental disease or shows the Islamic suicides as martyrs, which is also written in the Quran: "And do not say about those who are killed in the way of Allah, they are dead. Rather, they are alive" (Quran 2:154, 3:169, 4:74), what causes the appearance of "human bombs" [21]. It seems that one could prove the interdependence between high religiosity in Islam and suicides also among children, obviously if such studies were possible to conduct [21]. The suicides of the Islamic children, apart from high religiosity of both, children and parents, may be caused by the lies of adults, who claim that a kid, being a human bomb, will survive because will be protected. An adult makes such statement in a sense of life after death, while a child understands it typically for its age, that is literally. The kids want to live, therefore what triggers them may be the fear of an adult, an upbringing in the regime of orders and absolute obedience, as well as trust to an adult who promises that the child will survive, despite everybody around will die [22, 23].

What is also worrying, is a kind of "suicide fashion", appearing as an extended suicide. The cases are known of the series of suicides happening after the first one in a certain town: "If he did it - other desperate people think, I can do it as well", or suicidal blogs and adverts: "I am looking for somebody who will commit a suicide together with me" $[13,24,25,26]$.

The police statistics show that in the Lesser Poland and in the Subcarpathian region - the areas not too rich, but respecting tradition and cultivating religiosity, the number of suicide attempts and committed suicides is significantly less [27]. It is in accordance with the conducted analysis of the suicide attempts among children.

The undiscussed in the present article issue is further existence of those who remain, that is parents and siblings of a suicide. Such situation may be a cause of another suicide. The parents often blame each other, but also look for the reasons of such a step in themselves. Tense atmosphere of mourning is not a good environment for upbringing of the remaining kids. They usually have to support their parents, sometimes replace them in the role of carers towards younger siblings, not having their own time for grief and for further happier life. They may also feel that they are worth less than the child who passed away. It is not a healthy situation, and the following tragedy may be separation of parents. At the same time, it is hard to look for support in the environment, which, in a way, avoids the family of a suicide $[15,28]$.

\section{SUMMARY}

Suicide attempts ending up in death in 2018 accounted for $2.30 \%$ of suicide attempts undertaken in Lublin, while in Poland they constituted $1.87 \%$. The main reasons for suicide attempts among minors are: lack of acceptance, low self-esteem and peer violence, both physical and mental. Mass media have an influence on juvenile suicides, especially on, so called, extended suicides. Desperate sending warning signals, which become understandable for the family only after the suicide attempt, and perhaps the hope that somebody will come in time to save your life, and at the same time belief in "multiple lives" perpetuated by computer games and movies, may have impact on making suicide attempts. By contrast, a protective umbrella may be an example and everyday life of parents, faith and tradition requiring respect for life, and giving the feeling of acceptance and belonging. A vital issue is further life of the family of a child who died due to a suicide attempt.

\section{Próby samobójcze podejmowane w wieku 10-18 lat w Lublinie}

\section{WPROWADZENIE}

W ostatnich latach obserwuje się wzrost liczby dzieci i młodzieży objętych specjalistyczną pomocą psychiatryczną lub psychologiczną z powodu zaburzeń psychicznych. Z analizowanych danych [1] wynika, że w 2015 roku z pomocy specjalistycznej skorzystało ponad 143 tys. dzieci i młodzieży do 18. roku życia, z czego $61 \%$ to chłopcy. W tym czasie odnotowano 481 prób samobójczych, wśród których, aż 12 było podjętych przez dzieci do 12. roku życia. Analiza wskazuje również, że pod względem liczebności, samobójstwa były drugą przyczyną zgonów w grupie wiekowej 10-19 lat. Częściej próby samobójcze zakończone zgonem podejmowali chłopcy. Polska w 2014 roku znalazła się na drugim miejscu w Europie (po Niemczech) pod względem liczby prób samobójczych zakończonych zgonem wśród dzieci i młodzieży do 19. lat [1]. Doświadczenie przemocy w dzieciństwie nie tylko jest przyczyną obrażeń fizycznych czy zaburzeń rozwoju psycho-społecznego, ale może doprowadzić do ryzyka bycia sprawcą przemocy, zaburzeń psychicznych, lęków, samookaleczenia, prób samobójczych czy też podejmowania innych zachowań autodestrukcyjnych $[2,3,4,5]$.

Podczas analizy zagadnienia samobójstw przerażający jest fakt, że prób samobójczych dokonują dzieci do 12 roku życia. W 2014 roku w Polsce w tej grupie odnotowano 14 prób, przez dwa kolejne lata liczba malała, a w 2017 roku ta liczba się podwoiła. W analizowanych latach (2014-2018) najwięcej prób samobójczych w Polsce ogółem dokonano w Katowicach, Krakowie i Łodzi. 
Miało to również odzwierciedlenie w liczności podjętych prób samobójczych w grupie wiekowej 13-18 lat. Zauważono wzrost w pięcioletniej obserwacji o 42,63\% prób samobójczych w tej grupie. Tendencję wzrostową liczby osób w zamachach samobójczych ogółem odnotowano w pięcioletniej obserwacji w Lublinie $(13,07 \%)$ i w Polsce $(8,60 \%)$. Przeanalizowano również dane dotyczące zamachów samobójczych zakończonych zgonem. Zarówno w Lublinie i na obszarze całej Polski obserwowano tendencję malejącą wśród liczby osób, które dokonały zamachu samobójczego zakończonego zgonem w populacji ogółem. Najczęściej do czynów samobójczych i czynów samobójczych zakończonych zgonem w Polsce w analizowanym okresie dochodziło w poniedziałek [6].

\section{CEL PRACY}

Celem pracy była analiza występowania prób samobójczych wśród nieletnich na przykładzie miasta Lublina.

\section{MATERIAŁ I METODA}

Dokonano analizy danych statystycznych uzyskanych z Komendy Głównej Policji [6] i na podstawie Raportu Fundacji Dajemy Dzieciom Siłę „Dzieci się liczą 2017” [1] oraz przegląd literatury przedmiotu za lata 2014-2018 opracowane za pomoca metody opisowej. Dane dotyczyły zamachów samobójczych zakończonych zgonem z wyszczególnieniem: grupa wiekowa, dzień tygodnia, miejsce i powód, informacja o nauce. Do analiz włączono grupę wiekową: 7-12 i 13-18 lat. Grupa wiekowa 0-6 lat została wyłączona $\mathrm{z}$ analiz, ponieważ nie odnotowano w tym przedziale wiekowym prób samobójczych.

\section{WYNIKI}

W grupie wiekowej 7-12 lat w Lublinie w pięcioletniej obserwacji tendencja jest stała. W 2014 roku były trzy próby samobójcze, w 2015 roku odnotowano jedną, w 2016 - nie podjęto żadnej próby samobójczej, w 2017 - były już cztery, a w 2018 - trzy próby samobójcze. W Polsce w pięcioletniej obserwacji omawianej grupy wiekowej tendencja była zdecydowanie wzrostowa i wyniosła 46,15\%. W 2014 roku odnotowano 14 prób, przez kolejne dwa lata liczba zmniejszyła się (w 2015 - 12, w 2016 - 9 prób), w 2017 roku liczba podjętych prób samobójczych w omawianej grupie wiekowej zwiększyła się o $100 \%$ i wynosiła 28, a w 2018 roku zmniejszyła się nieznacznie (26 prób samobójczych) [6].

Podobną tendencję, zarówno w Lublinie i w Polsce, obserwowano w grupie wiekowej 13-18 lat. W Lublinie w pięcioletnim okresie obserwacji zaobserwowano wzrost prób samobójczych o 26,19\%. W 2014 roku odnotowano 31, w 2015 - 25, w 2016 - 20, w 2017 - 26, a w 2018 roku były już 42 próby samobójcze (wykres 1). W Polsce również zaobserwowano tendencję wzrostową podjętych prób samobójczych w omawianej grupie i przedziale czasowym o 42,63\%. W 2014 roku odnotowano 428 prób samobójczych, w 2015 - 469, w 2016 niewielki spadek do 466, w 2017 - wzrost do 702 i w 2018 roku było już 746 prób samobójczych [6].

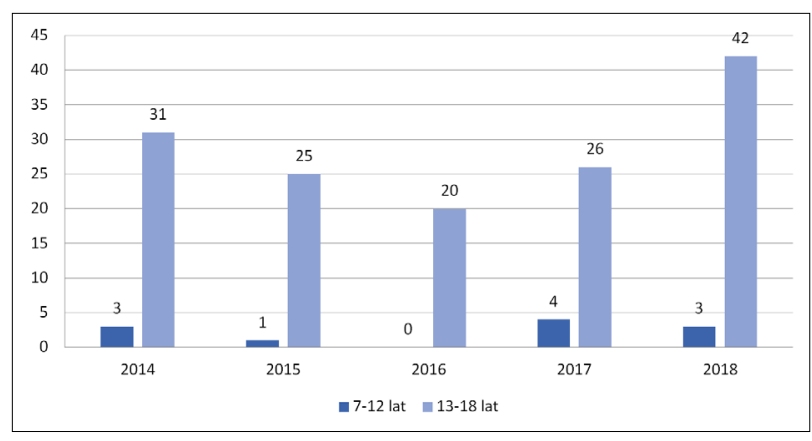

Ryc 1. Próby samobójcze wśród dzieci i młodzieży w Lublinie w latach 2014-2018

Źródło: Opracowanie własne na podstawie danych statystycznych Komendy Głównej Policjii za lata 2014-2018.

Miejscem prób samobójczych w Lublinie, wśród dzieci i młodzieży były placówki opiekuńczo-wychowawcze oraz szkoła. Dane liczbowe za lata 2014-2016 są niedostępne. W Lublinie w placówkach opiekuńczo-wychowawczych odnotowano wzrost prób samobójczych o $60 \%$ w analizowanych latach. W 2017 roku podjęto 2 próby, a w 2018 - 5 prób samobójczych. W szkole obserwowano spadek dwu- i półkrotny. W 2017 roku dokonano 5, a w 2018 - dwie próby samobójcze. W Polsce odnotowano spadek czynów samobójczych w placówkach opiekuńczowychowawczych w analizowanych latach o 9,09\%. W 2017 roku odnotowano 48, a w 2018 - 44 próby samobójcze. W szkole, podobnie jak w Lublinie, obserwowano spadek prób samobójczych o 18,75\%. W 2017 roku dokonano 57, a w 2018 - 48 zamachów samobójczych w szkole [6].

W grupie wiekowej 7-12 lat w Lublinie w pięcioletniej obserwacji zamachów samobójczych zakończonych zgonem tendencja jest malejąca. W 2014 roku był jeden przypadek śmierci przy próbie samobójczej, natomiast w kolejnych latach (2015-2018) nie odnotowano przypadku śmiertelnego w wyniku czynu samobójczego. W Polsce w pięcioletniej obserwacji omawianej grupy wiekowej tendencja była zmienna i ostatecznie zanotowano wzrost o dwa przypadki śmiertelne. W 2014 roku odnotowano 3 zgony, w 2015 nastąpił wzrost do pięciu, w 2016 - spadek do dwóch, w 2017 - spadek do jednego zgonu, a w 2018 roku zanotowano pięć przypadków zgonów na skutek zamachów samobójczych [6].

Podobną tendencję, zarówno w Lublinie i w Polsce, obserwowano w grupie wiekowej 13-18 lat. W Lublinie w 2014 i 2015 roku odnotowano 10 przypadków, w 2016 11, w 2017 - spadek do pięciu, a w 2018 roku wzrost do 9 przypadków śmiertelnych na skutek podjętych prób samobójczych. Jednakże w pięcioletnim okresie obserwacji zaobserwowano spadek przypadków śmiertelnych. Podobnie sytuacja wyglądała w Polsce, czyli również zaobserwowano tendencję spadkową podjętych prób samobójczych w omawianej grupie i przedziale czasowym o $34,78 \%$. W 2014 roku odnotowano 124 samobójstwa, w 2015 - 114, w 2016 spadek do 101, w 2017 - wzrost do 115 i w 2018 roku były już 92 przypadki zgonów po zamachach samobójczych [6].

Samobójstwa wśród dzieci i młodzieży zakończone zgonem w Lublinie i w Polsce odnotowano w placówkach opiekuńczo-wychowawczych oraz szkole. Dane liczbowe za lata 2014-2016 są niedostępne. W Lublinie w placówkach 
opiekuńczo-wychowawczych nie odnotowano żadnych przypadków śmiertelnych na skutek czynów samobójczych. W szkole w 2017 i 2018 roku odnotowano jeden przypadek śmiertelny w przebiegu próby samobójczej. W Polsce w placówkach opiekuńczo-wychowawczych odnotowano spadek przypadków śmiertelnych z trzech w 2017 do dwóch w 2018 roku. W szkole w Polsce na skutek podjętych czynów samobójczych, zakończonych śmiercią było siedem [6].

Badania $[7,8,9,10,11]$ pokazują, że najczęstszymi powodami zamachów samobójczych wśród dzieci i młodzieży było uczucie emocjonalnego odtrącenia przez rodziców, konflikty z rodzicami, śmierć jednego lub obojga rodziców, alkoholizm rodziców, konflikty pomiędzy rodzicami, struktura rodziny, konflikty z rodzeństwem, brak religijności w rodzinie, kradzież pieniędzy rodzinie, trudności w relacjach $\mathrm{z}$ kolegami, posiadanie lub nieposiadanie sympatii, zawody miłosne, niska pozycja $\mathrm{w}$ grupie, zakazy obowiązujące w grupie, przestrzeganie regulaminów, niemożność realizacji własnej drogi życiowej, niepokój z wchodzeniem w nowe role społeczne, trudność w podejmowaniu dojrzałych decyzji, niepokój związany z ustanowieniem własnej tożsamości psychoseksualnej, problemy z dojrzewaniem biologicznym, brak akceptacji własnego wyglądu.

\section{DYSKUSJA}

Jak wykazano, niestety odsetek samobójstw wśród dzieci wzrasta. Jest to zjawisko niepokojące i wymagające prewencji. Równocześnie należy sobie zdawać sprawę $\mathrm{z}$ tego, że w pewnych niekorzystnych warunkach, zbiegu okoliczności, zdarzeń i przykrych doświadczeń, każdy człowiek może doświadczać myśli samobójczych [12].

Psychiatrzy określają stan osoby planującej samobójstwo jako „tunelową wizję”, czyli taki stan, w którym wydaje się, że nie ma już nadziei i jedyną ucieczką przed cierpieniem może być tylko zniszczenie własnej świadomości, swego istnienia. Nie jest to jednak dyspozycja stała i niezmienna, bo w przypadku zmniejszenia cierpienia na skutek zaspokojenia pewnej potrzeby, do próby samobójczej nie dojdzie. Stąd pewne sygnały ostrzegawcze wysyłane wcześniej przez część potencjalnych samobójców [13], będących niejako szansą dla otoczenia na zaspokojenie potrzeby i uwolnienie od myśli samobójczych [14].

Przyczyny samobójstwa dzieci mnogą być różne, ale jest to zawsze poczucie braku bezpieczeństwa wynikające np. z rozłąki z przyjacielem czy ukochaną osobą, spowodowanym przeprowadzką, czy kłótniami rodziców, przemocą w rodzinie, której dziecko zaradzić nie może, czy też wyróżnianie się z klasy, nieakceptowane zarówno przez koleżanki i kolegów, jak i nauczyciela. Jednak najgorsze jest to, że nawet kiedy dziecko czy nastolatek komunikuje rodzicom swoje problemy, to jest to bagatelizowane, a dziecko pozostaje $\mathrm{z}$ problemem, $\mathrm{w}$ jego mniemaniu nie do rozwiązania, zupełnie samo [15].

Z badań nowojorskich psychiatrów przeprowadzonych w grupie 321 osób cierpiących na depresję lub chorobę afektywną dwubiegunową wynikało, że osoby bardziej religijne (bez względu na religię) częściej dokonywały prób samobójczych - iloraz szans 2,25 [16]. Natomiast praktyką stało się pobudzanie przez lekarzy psychiatrów duchowości u pacjentów w celu nie dopuszczenia do próby samobójczej, ponieważ duchowość i ofiarowana przez nią pociecha, poznanie i akceptacja zdarzeń oraz okoliczności napotykanych przez pacjenta stanowi ucieczkę od prób samobójczych [14, 17]. Zaznaczyć jednak należy, że wg opublikowanych w 2018 roku badaniach prowadzonych przez Instytut Psychiatryczny Stanu Nowy York i Uniwersytet Columbia - religijność rodziców powoduje mniejszą szansę popełnienia próby samobójczej przez dzieci. Były to badania trwające 30 lat i obejmujące 3 pokolenia, 112 rodziców. Związki istotne statystycznie wykazano między poczuciem, że religia jest ważna a mniejszym prawdopodobieństwem prób samobójczych. Stwierdzono związek między praktykami religijnymi, praktykami religijnymi a niższym prawdopodobieństwem zachowań samobójczych w grupie dziewcząt, natomiast wyższa religijność rodziców była powiązana z mniejszym ryzykiem myśli i prób samobójczych zarówno wśród chłopców, jak i dziewcząt. Być może wiąże się to $\mathrm{z}$ obserwacją codziennego życia rodziców, którzy stanowią wzorzec dla dziecka. Odnajdują oni sens w wierze i są częścią wspólnoty, co powoduje powstanie swoistego parasola chroniącego dziecko przed myślami i próbami samobójczymi, a zwłaszcza konstrukcji, w którą wchodzi poczucie przynależności, akceptacji i sensu życia [18].

Okazuje się jednak, że nie każda religia chroni przed samobójstwami. Samobójstwo to wykroczenie przeciw przykazaniu „Nie zabijaj” w judaizmie i chrześcijaństwie, potępiane w kardecyźmie, buddyzmie, hinduizmie i islamie [14]. Chociaż w Koranie czytamy: „A kto zabija wiernego celowo, jego zapłatą będzie Piekło i wieczny w nim pobyt i klątwa Allaha ciążą na nim, i surowa kara przygotowana jest dla niego" (Koran 4:93) [19] to równocześnie tłumaczenie Szeicha Usajmîna, głosi: „Z sunny Proroka dowiadujemy się: „Zaprawdę, ktokolwiek się zabije (umyślnie), z pewnością zostanie ukarany Piekłem, w którym będzie przebywał na zawsze" [al.-Buchari, 5778 i Muslim: 109, 110]. Zatem, ten kto popełnia samobójstwo, popełnia je głównie ze względu na trudną sytuację, w której się znajduje, będącą bezpośrednim wynikiem działań Allaha lub innego człowieka. Nie jest on w stanie poradzić sobie z tym, co go dotknęło, i jest niczym osoba, która woła o pomoc z palących płomieni ognia. A zatem odszedł od tego, co było złe, do tego co było gorsze. A gdyby był cierpliwy, wówczas Allah mógłby mu pomoc poradzić sobie z trudnościami" [20]. Natomiast obserwowana rzeczywistość przynosi usprawiedliwienie samobójców chorobą psychiczną czy ukazuje islamskich samobójców jako męczenników, co także wyczytywane jest z Koranu, mówiącego: „I nie uważaj tych, którzy zostali zabici na drodze Boga, za umarłych. Przeciwnie, oni są żyjący" (Koran 2:154, 3:169, 4:74), co powoduje powstawanie „żywych bomb” [21]. Wydaje się, że można byłoby dowieść związku wysokiej religijności w islamie z samobójstwami, także w grupie dzieci, gdyby oczywiście takie badania byłyby możliwe do przeprowadzenia [21]. Samobójstwa dzieci islamskich, oprócz wysokiej religijności zarówno dzieci, jak i rodziców, mogą być spowodowane 
kłamstwem osób dorosłych, które twierdzą, że dziecko, będące żywą bombą przeżyje, gdyż zostanie ochronione. Dorosły wygłasza takie stwierdzenie w sensie życia po śmierci, zaś dziecko rozumie je w typowy dla wieku sposób, czyli w sensie dosłownym. Dzieci chcą żyć, więc może tu wchodzić w grę strach przed dorosłym, wychowanie w reżimie nakazów i bezwzględnym posłuszeństwie, a także zaufanie do osoby dorosłej, która obiecuje, że dziecko przeżyje, chociaż dookoła wszyscy zginą [22, 23].

Bardzo niepokojąca jest też swoista „moda na samobójstwo”, jawiąca się jako samobójstwo rozszerzone. Znane są przypadki szeregu samobójstw występujących po pierwszym w danej miejscowości: „Jeśli tamten to zrobił - myślą kolejni desperaci, mogę i ja”, czy też samobójcze blogi i ogłoszenia: „Szukam kogoś, kto razem ze mną odbierze sobie życie" [13, 24, 25, 26].

Ze statystyk policyjnych wynika, że w Małopolsce i na Podkarpaciu - rejonach niezbyt bogatych, ale szanujących tradycję i pielęgnujących religijność, prób samobójczych i dokonanych samobójstw jest zdecydowanie mniej [27]. Jest to zgodne z przeprowadzoną analizą podejmowanych prób samobójczych przez dzieci.

Kwestią nie podjętą w artykule jest dalsza egzystencja tych, którzy pozostają, a więc rodziców i rodzeństwa samobójcy. I znów ta sytuacja może stać się przyczyną kolejnego samobójstwa. Między rodzicami często dochodzi do wzajemnego obwiniania się, ale też i szukania przyczyn takiego kroku u siebie. Napięta atmosfera żałoby nie jest dobrym środowiskiem do wzrostu dla pozostałych dzieci. Zwykle muszą udzielać wsparcia rodzicom, nieraz zastępować ich w obowiązkach opiekuńczych wobec młodszego rodzeństwa, samym sobie nie dając czasu na przeżycie żałoby i dalsze już radośniejsze życie. Mogą mieć też poczucie niższej wartości niż to dziecko, które odeszło. Nie jest to zdrowa sytuacja, a kolejną tragedią może być rozstanie się rodziców. Równocześnie ciężko szukać wsparcia w środowisku, które niejako unika rodziny samobójcy $[15,28]$.

\section{PODSUMOWANIE}

Próby samobójcze nieletnich zakończone zgonem w 2018 roku stanowiły 2,30\% prób samobójczych podjętych w Lublinie, zaś w Polsce stanowiły 1,87\%. Głównymi powodami prób samobójczych podejmowanych przez nieletnich są: brak akceptacji, niska samoocena oraz przemoc rówieśnicza zarówno fizyczna jak i psychiczna. Mass media mają wpływ na podejmowane samobójstwa przez nieletnich, a zwłaszcza na tak zwane samobójstwo rozszerzone. Desperackie wysyłanie sygnałów ostrzegawczych, które stają się zrozumiałe dla bliskich dopiero po podjęciu próby samobójczej i być może nadzieja, że ktoś zdąży uratować życie, a równocześnie wiara w „kilka żyć” utrwalana poprzez gry komputerowe i filmy, może mieć wpływ na podejmowanie prób samobójczych. Natomiast parasolem ochronnym może być przykład i codziennego życia rodziców, wiara i tradycja, nakazująca szacunek dla życia, a także dająca poczucie akceptacji i przynależności. Istotną kwestią jest także dalsze życie bliskich dziecka, którego próba samobójcza zakończyła się śmiercią.

\section{ORCID}

Małgorzata Pabiś (iD https://orcid.org/0000-0001-7260-8996

Kinga Augustowska-Kruszyńska (D) https://orcid.org/0000-0001-8130-2788

\section{REFERENCES/PIŚMIENNICTWO}

1. Sajkowska M. (red. naczelna): Dzieci się liczą 2017. Raport 0 zagrożeniach bezpieczeństwa i rozwoju dzieci w Polsce. Fundacja Dajemy Dzieciom Siłę. Dziecko krzywdzone. Teoria, badania, praktyka. 2017; 16(1).

2. Szmajda R, Gmitrowicz A. Selected mental health problems in institutionally reared children (Wybrane problemy z zakresu zdrowia psychicznego wśród nastolatków w wychowaniu instytucjonalnym). Psychiatria i Psychologia Kliniczna. 2018; 4(18), 354-363.

3. Włodarczyk J. Śmierć dzieci jako konsekwencja krzywdzenia i/lub zaniedbania. Dziecko krzywdzone. 2012; 2(39), 104-115.

4. Mrozek A. Dziecko maltretowane inaczej. Psychiatria i Psychologia Kliniczna. 2005; 5(2), 79-86.

5. Rutkowska A, Łopuszańska U, Świder K, et al. The analysis of family risk factors associated with the occurrence of suicidal attempts among girls aged 12-16 years old. A pilot study (Analiza rodzinnych czynników ryzyka występowania prób samobójczych w grupie dziewcząt w wieku 12-16 lat. Badania pilotażowe). Psychiatria i Psychologia Kliniczna. 2015, 15(3), 126-130.

6. Statystyki Komendy Głównej Policji: http://statystyka.policja.pl/st/wybranestatystyki/zamachy-samobojcze [dostęp 05.07.2019].

7. Makara-Studzińska M. Przyczyny prób samobójczych u młodzieży w wieku 14-18 lat. Psychiatria. 2013; 10(2), 76-83.

8. Putowski M, Piróg M, Podgórniak M, i wsp. Analiza epidemiologiczna występowania samobójstw w Polsce w latach 2000-2013. Problemy Higieny i Epidemiologii. 2015, 96(1), 264-268.

9. Stradomska M, Wolińska J, Marczak M. Circumstances and underlying causes of suicidal attempts in teen patients of mental health facilities - a psychological perspective (Uwarunkowania prób samobójczych u nastoletnich pacjentów szpitali i klinik psychiatrycznych w perspektywie psychologicznej). Psychiatria i Psychologia Kliniczna. 2016; 16(3), 136-149.

10. Krajewska K, Florkowski A, Gmitrowicz A. Związek zespołu zależności alkoholowej rodziców z występowaniem prób samobójczych wśród nastoletnich pacjentów hospitalizowanych psychiatrycznie. Psychiatria i Psychologia Kliniczna. 2014; 14(3), 196-201.

11. Makara-Studzińska M, Łopuszańska U, Sidor K, i wsp. Violence, suicidal attempts and relationships with parents in a group of adolescent girls. Pilot studies (Doświadczanie przemocy ze strony rówieśników, próby samobójcze i relacje z rodzicami w grupie nastoletnich dziewcząt. Badania pilotażowe). Psychiatria i Psychologia Kliniczna. 2017, 17(3), 172-178.

12. Chwin S. Samobójstwo jako doświadczenie wyobraźni. Gdańsk 2010.

13. Pietkiewicz B. Samobójstwo zaraźliwe jak choroba. W: https://www.polityka.pl/ tygodnikpolityka/spoleczenstwo/1521747,1,samobojstwo-zarazliwe-jak-choroba [dostęp: 09.07.2019].

14. Kropidłowski M. Religie wobec samobójstwa. W: http://www.racjonalista.pl/ kk.php/s,3948 [dostęp: 11.07.2019].

15. Galińska I. Życiowy tunel. https://opoka.org.pl/biblioteka///IP/niedziela201505samobojstwo.html [dostęp: 09.07.2019].

16. Lawrence RE, Brent D, Mann JJ, et al. Religion as a Risk Factor for Suicide Attempt and Suicide Ideation Among Depressed Patients. The Journal of Nervous and Mental Disease: November 2016, Volume 204, Issue 11, 845-850. https://journals.Iww. com/jonmd/Abstract/2016/11000/Religion_as_a_Risk_Factor_for_Suicide_ Attempt_and.8.aspx [dostęp: 05.07.2019].

17. Szczepaniak W. Ludzie religijni są zdrowsi i dłużej żyją. STACJA 7.pl 2017. https:// stacja7.pl/styl-zycia/ludzie-religijni-sa-zdrowsi-i-dluzej-zyja [dostęp: 11.07.2019].

18. Gałek M. Religijność rodziców ma związek z mniejszym ryzykiem samobójstw u dzieci. https://pl.aleteia.org/2019/03/27/religijnosc-rodzicow-ma-zwiazek-zmniejszym-ryzykiem-samobojstw-u-dzieci/ (za): Carroll L.: Parents' spirituality or religion tied to lower suicide risk in kids. Reuters Health News, 09.08.2018. [dostęp: 12.07.2019].

19. Bielawski J. (tł.): Koran. Opracowanie zbiorowe, PIW, 2014.

20. Samobójstwo a Islam. https://sites.google.com/site/bankfatw/postepowaniemzlmnina/9-grzech-i-wystepek/samobojstwo-d-islam [dostęp: 12.07.2019].

21. Caschetta AJ. Does Islam Have a Role in Suicide Bombings? (0to jak islam inspiruje samobójcze zamachy!). Middle East Quaterly 2015, 22 (3), 1-19. https://www. meforum.org/5320/islam-suicide-bombings; https:/www.fronda.pl/a/oto-jakislam-inspiruje-samobojcze-zamachy,66263.html [dostęp: 12.07.2019]. 
22. Farmer B. W Afganistanie dzieci stają się bombami. https://euroislam.pl/wafganistanie-dzieci-staja-sie-bombami [dostęp: 12.07.2019].

23. Caschetta AJ. Jak islam inspiruje samobójcze zamachy. https://euroislam.pl/jakislam-inspiruje-samobojcze-zamachy [dostęp: 12.07.2019].

24. Galińska I. Samobójstwo dziecka.Życiowy tunel. Niedziela - Tygodnik Katolicki 2015 https://opoka.org.pl/biblioteka/I/IP/niedziela201505-samobojstwo.html [dostęp: 09.07.2019].

25. Pietryga E, Kozik K. Samobójstwa dzieci i młodzieży. Przyczyny samobójstw. Rzeczpospolita 2012. https://www.rp.pl/artykul/804697-Samobojstwa-dzieci-imlodziezy--Przyczyny-samobojstw.html [dostęp: 08.07.2019].

26. Cieśla J. Nastolatki w głębokiej depresji. Polityka 2012. https://www.polityka.pl/ tygodnikpolityka/spoleczenstwo/1530421,1,nastolatki-w-glebokiej-depresjidlaczego [dostęp: 11.07.2019].

27. Czapiński J. Religia i tradycja chronią przed samobójstwem. MT/dziennik.pl 2015. https://www.fronda.pl/a/religia-i-tradycja-chronia-przed-samobojstwem,58444. html [dostęp: 09.07.2019].

28. Pietkiewicz B. Dramaty rodzin młodych samobójców. https://www.polityka. $\mathrm{pl} /$ tygodnikpolityka/spoleczenstwo/1571341,1,dramaty-rodzin-mlodychsamobojcow [dostęp: 09.07.2019].
Manuscript received/Praca zgłoszona do czasopisma: 26.07.2019

Manuscript accepted/Praca zaakceptowana do druku: 23.10.2019

Translation/Tłumaczenie: Weronika Topolan, UM w Lublinie 